\title{
Detection of Horizontal Transfer of Housekeeping and Hydrocarbons Catabolism Genes in Bacterial Genus with Potential to Application in Bioremediation Process
}

\author{
Edmo Montes Rodrigues*, Fernanda de Souza Freitas, Tatiane de Paula Siqueira \\ Laboratory of Environmental Biotechnology and Biodiversity, Microbiology Department, Federal University of Viçosa, Viçosa, \\ Minas Gerais, Brazil \\ Email: *edmomontes@yahoo.com.br
}

How to cite this paper: Rodrigues, E.M., Freitas, F. de S. and Siqueira, T. de P. (2018) Detection of Horizontal Transfer of Housekeeping and Hydrocarbons Catabolism Genes in Bacterial Genus with Potential to Application in Bioremediation Process. Open Access Library Journal, 5: e4454. https://doi.org/10.4236/oalib.1104454

Received: February 28, 2018

Accepted: March 12, 2018

Published: March 15, 2018

Copyright $\odot 2018$ by authors and Open Access Library Inc.

This work is licensed under the Creative Commons Attribution International License (CC BY 4.0).

http://creativecommons.org/licenses/by/4.0/

\begin{abstract}
In silico analysis can be useful to infer about the horizontal gene transfer (HGT) as well as to deduce about the evolutionary relations of catabolic genes. In this study, we performed the analysis of two housekeeping genes ( $f a b D$ and $r p o D$ ) and two catabolic genes (alkB and catA) from 12 bacterial genus usually founded in marine environments. Comparing the trees obtained from Bayesian Inference hypotheses of these genes with $16 \mathrm{~S}$ rDNA sequences, we noted the topologies are different among housekeeping or catabolic genes trees comparing to $16 \mathrm{~S}$ gene tree. The HGT may be used with the purpose to spread genes within bacterial community according to environmental conditions in marine ecosystems. In this way, using our analysis, we concluded that hydrocarbons catabolism genes as well as housekeeping genes can be subject to horizontal gene transfers among marine bacterial communities.
\end{abstract}

\section{Subject Areas}

Bioinformatics, Ecology, Ecosystem Science, Evolutionary Studies, Marine Biology, Microbiology, Molecular Biology

\section{Keywords}

Bacterial Community, Microbial Ecology, Gene Transfer, Catabolic Genes

\section{Introduction}

The phylogeny of bacteria has received very attention and discussion on micro- 
bial ecology. Molecular structures and genomics sequences have been used to infer phylogenetic hypothesis among different organisms [1] [2] [3]. On the last decades, morphological characteristics ceased to be the main default to compare microorganisms and the improvement of molecular techniques contributed to new data that could help on the classification of organisms [4] [5]. Woese et al. (1990) [2] showed in a study based on small subunit ribosomal RNA (SSU rRNA 16S) that the life in our planet should be divided into three primary groups of organisms: Bacteria, Eukaria and Archaea. However, different topologies are generated when phylogenetic hypotheses are made with other genes.

In Bacteria domain the different topologies can be result of horizontal gene transfers (HGTs) that occur frequently in these organisms [6] [7]. Nakamura and his collaborators (2004) [8] revealed that considerable proportions of most bacterial genomes consist of horizontally acquired genes and the HGT provides basis for quantitatively understanding the evolution of the prokaryotic genome. Many events of HGT occur likely to cause deleterious effects in the chromosome of the host, whereas other acquisitions might be effectively neutral. However, the HGT that confers a selective advantage to the bacterial recipient has potential to spread rapidly within a bacterial population as well as mobile genetic elements that encode their own transfer and maintenance functions [6]. Despite of genes of the central cellular machinery such as replication, maintenance, transcription and translation which tend not to spread within a population, some housekeeping genes were reported in integrative and conjugative elements [9].

Petroleum hydrocarbons enter the environment directly of accidents, spills during transportation and extraction, leakage from waste disposal or storage site and industrial facilities [10]. The entry of petroleum in marine environments receives attention because it causes many problems. Polycyclic aromatic hydrocarbons (PAH) are present as natural constituents in crude oil and are highly recalcitrant. The size of the hydrocarbon molecule is inversely proportional to its volatility, water solution and possibility to be degraded by microorganisms [11] [12]. These compounds perform chronic effects on the local biota, like endocrine deregulation, stress, affect the competition for food, and are carcinogenic and other physiological effects [13] [14] [15] [16] [17]. Many hydrocarbons are very hydrophobic and their persistence within the ecosystem is due largely to their hydrophobicity and low water solubility [18]. Exposure of aquatic habitats and organisms to whole oil and toxic components causes acute mortality and chronic effects that can be felt during several years [16] [19] [20].

Some bacteria found in contaminated environments with oil show the ability to metabolize many hydrocarbons and mineralizing this organic matter [21]. The degradation of many hydrocarbon compounds is known to be mediated by plasmid encoded enzymes [22]. The bacteria known to degrade PAHs and others hydrocarbons have many of the genes often located on plasmids [23]. A plasmid may encode a complete degradative pathway or partial degradative step. Some plasmids may allow the host to grow on several hydrocarbons as sole carbon and 
energy sources [24].

The importance of HGT is strictly related with the construction of new plasmids and genomes to allow the evolutionary success [25]. Bosma et al. (2001) [26] showed that slightly differs from homologous operons, encoding for catabolic pathways have been found frequently in phylogenetically distant organisms, suggesting the occurrence of extensive HGT. This work aimed demonstrates the utility of molecular phylogenetic methods in studies of horizontal transfer of functional genes of crude oil degradative pathways in bacteria.

\section{Materials and Methods}

\subsection{Nucleotide Sequences}

The complete nucleotide sequences of $16 \mathrm{~S}$ rRNA genes used in present study (Table 1) were obtained from European Molecular Biology Laboratory-EMBL (http://www.ebi.ac.uk/genomes/bacteria.html) and the others sequences were obtained from the National Center for Biotechnology Information-GenBank (http://www.ncbi.nlm.nih.gov). For analyses involving the alk $B$ and cat $A$ genes, 12 sequences were selected (Table 1) from 12 different bacterial genus. Others two housekeeping genes were searched, $r p o D$ and $f a b D$ genes (Table 2) for the same bacterial genus. Functionally, the 16S, housekeeping genes and catabolic genes are unrelated to the others. The choices were made to evaluate the phylogenetic relationships of these taxonomic groups and try to relate them.

\subsection{Phylogenetic Analysis}

Previously all the sequences, except of $16 \mathrm{~S}$ rRNA, were translated into amino

Table 1. Bacterial genus and NCBI accession number of $r p o D$, fabD, alkB and $c a t A$ sequences used in this work.

\begin{tabular}{|c|c|c|c|c|}
\hline \multirow{2}{*}{ Bacterial Genus } & \multicolumn{4}{|c|}{ NCBI Accession Numbers } \\
\hline & $r p o D$ & $f a b D$ & alkB & catA \\
\hline Acinetobactersp. & СР001172.1 & СР001172.1 & СР000521.1 & AF009224.2 \\
\hline Arthrobactersp. & СР000474.1 & СР000454.1 & FJ014912.1 & AJ000187.1 \\
\hline Burkholderia sp. & СР009147.1 & СР000614.1 & СР003774.1 & СР001052.1 \\
\hline Corynebacterium sp. & СР008924.1 & AP009044.1 & СР003696.1 & СР005959.1 \\
\hline Gordonia sp. & СР003119.1 & СР001802.1 & AB112870.1 & СР001802.1 \\
\hline Marinobactersp. & СР003735.1 & СР003735.1 & FO203363.1 & FO203363.1 \\
\hline Mycobacterium sp. & СР008980.1 & СР009100.1 & СР000580.1 & СР000656.1 \\
\hline Nocardia sp. & FO082843.1 & FO082843.1 & FO082843.1 & AP006618.1 \\
\hline Pseudomonas sp. & СР006832.1 & СР006832.1 & СР000076.1 & AE015451.1 \\
\hline Ralstonia sp. & AL646052.1 & FP885906.2 & СР001645.1 & СР001644.1 \\
\hline Rhodococcus sp. & СР003949.1 & AP008957.1 & HM771646.1 & AP008957.1 \\
\hline Streptomyces sp. & BA000030.3 & СР003990.1 & СР006259.1 & AF277051.1 \\
\hline
\end{tabular}


Table 2. Bacterial genus names and EMBL accession number of $16 \mathrm{~S}$ rRNA sequences used.

\begin{tabular}{cc}
\hline Bacterial Genus & EMBL Accession Numbers \\
\hline Acinetobacter $\mathrm{sp}$. & CP006768.1 \\
Arthrobacter $\mathrm{sp}$. & X80742.1 \\
Burkholderia sp. & CP000458.1 \\
Corynebacterium sp. & CP003697.1 \\
Gordonia sp. & CP002907.1 \\
Marinobacter $\mathrm{sp}$. & FO203363.1 \\
Mycobacterium sp. & CP009100.1 \\
Nocardia sp. & AP006618.1 \\
Pseudomonas $\mathrm{sp}$. & CP004061.1 \\
Ralstonia sp. & FP885897.1 \\
Rhodococcus $\mathrm{sp}$. & CP000431.1 \\
Streptomyces $\mathrm{sp}$. & CP003990.1 \\
\hline
\end{tabular}

acid sequences for to do the aligning with Clustal W in MEGA 6.0 software [27]. The individuals' phylogenetic hypothesis were performed with Baysian inference [28] with MrBayes 3.1 [29] to the five set of genes. To infer the tree through the Bayesian inference made two independent analyses with four chains each, one cold and three hot chains. Bayesian phylogenetic analyses were conducted by Markov Chain Monte Carlo simulations (MCMC) for 10 million generations. The likelihood was checked after burned-out $25 \%$ of the trees and to construct the consensus tree.

\section{Results and Discussion}

The Bayesian Inference hypotheses for the 16S gene are shown in Figure 1, which presents the expected pattern of genus.

In the Figure 2 are showed the Bayesian Inference hypotheses for the $r p o D$ and $f a b D$ housekeeping genes. The topologies are different among both tree and these with $16 \mathrm{~S}$ gene tree. Gordonia, Nocardia and Rhodococcus are very near genus, however, appear no so much near on the $r p o D$ tree, these genus appear in over half of the disrupted mycobacterial clans, suggesting relatively short-distance transfers of genetic material either into or out mycobacterial species [30]. The genus Gordonia and Nocardia are distinct only by ability of Gordonia representants may reduce nitrate, which not occur with Nocardia [31] [32].

It is expected that molecular phylogenies based on single genes lead to apparently conflicting results with alternative branches [33]. This conflict is also observed in phylogenetic tree constructed from hydrocarbons catabolism genes, such as alkB and cat $A$ genes (Figure 3).

The conflicting topologies shown in Figures 1-3, with very different branches, suggesting that the all the four genes $(r p o D$, fabD, alkB, and cat $A$ ) were indeed subjected to horizontal transfer events among these bacterial genus. Yamamoto 


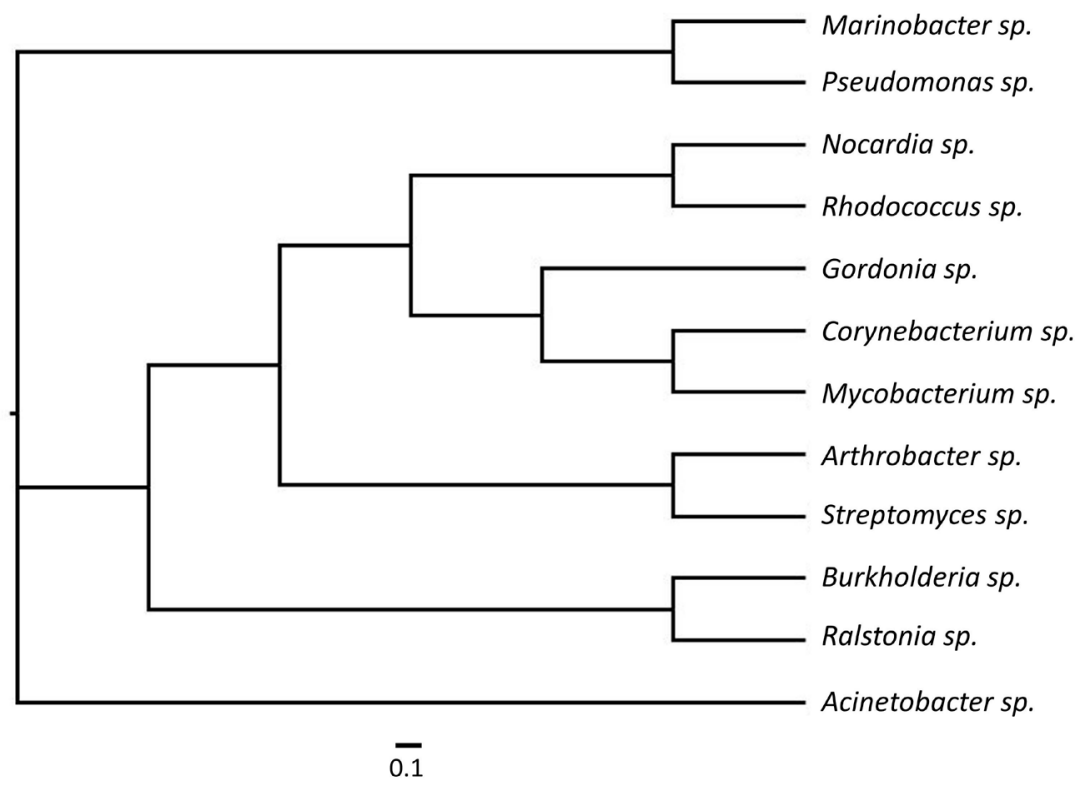

Figure 1. Tree obtained by Bayesian Inference analysis from sequences of the $16 \mathrm{~S}$ gene.
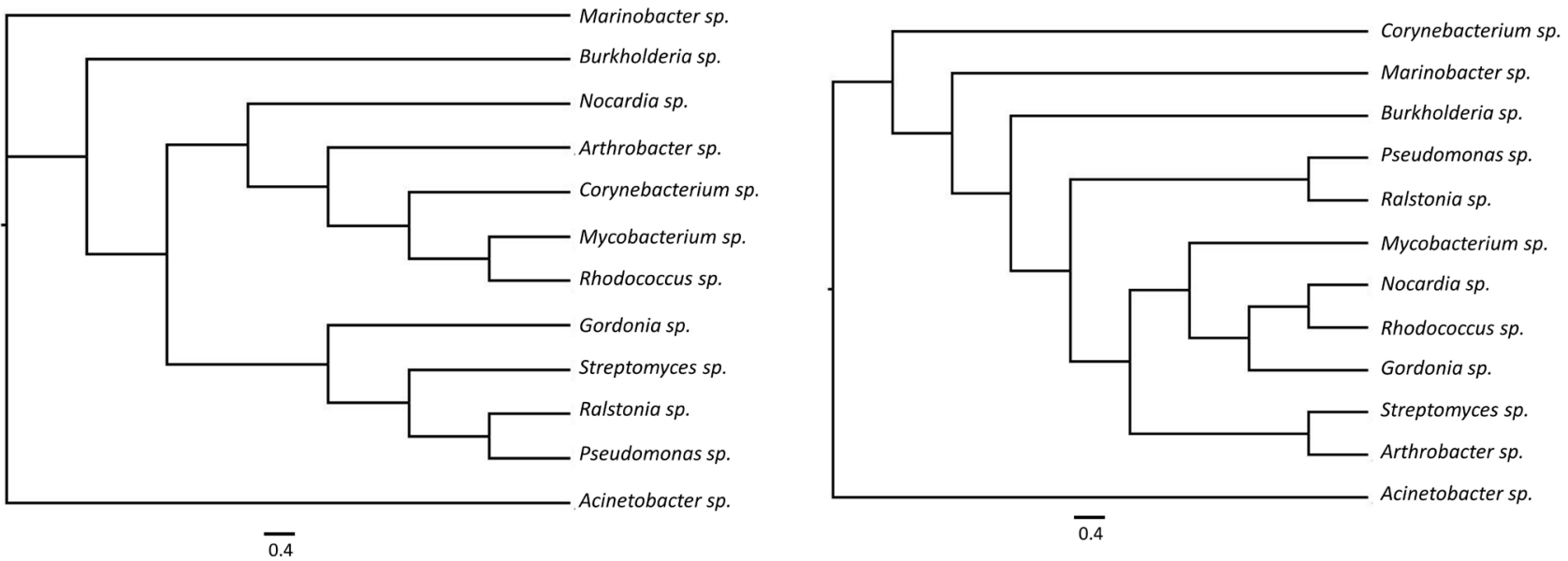

Figure 2. Trees obtained by Bayesian Inference analysis from sequences of the $r p o D$ (left) and fabD (right) housekeeping genes.

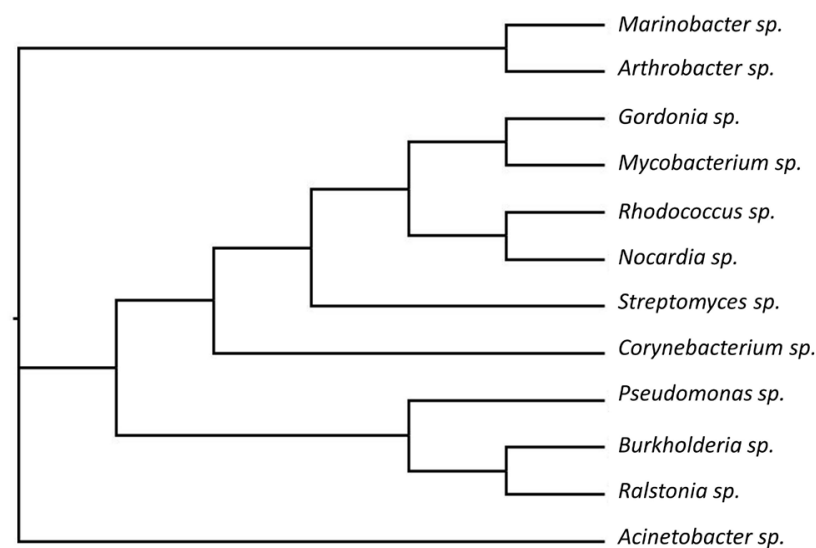

0.1

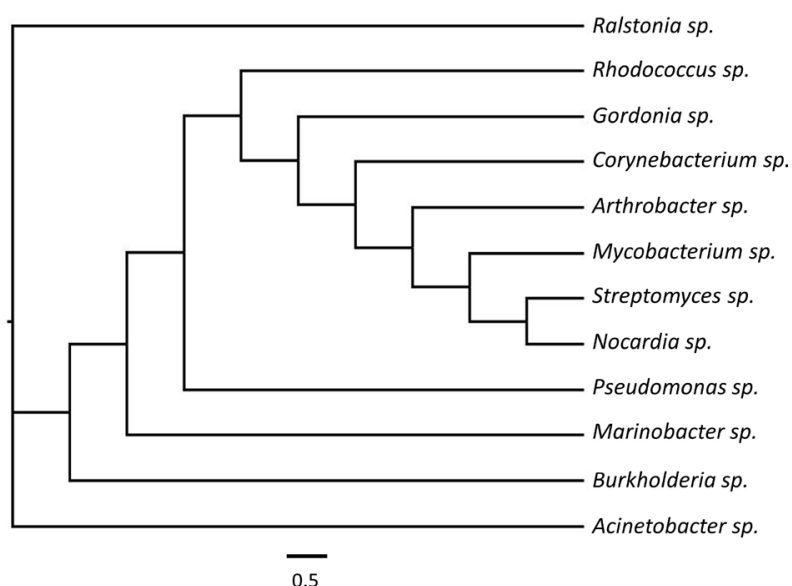

$\overline{0.5}$

Figure 3. Trees obtained by Baysean Inference analysis from sequences of the alkB (left) and cat $A$ (right) hydrocarbons catabolism genes. 
\& Harayama (1998) [34] suggested that the genetic distances among two housekeeping genes may be caused by single-event mutations introducing multiple substitutions. Soler et al. (2004) [35] observed that exist distinct nucleotide substitution rates between $g y r B$ and $r p o D$ sequences, so it may be a significant factor to driving the evolution of two housekeeping genes. In addition the possibility of horizontal gene transfer involving housekeeping genes not very likely, it must be taken into account. Because these doubts, the study of several housekeeping gene sequences and multilocus analysis has already been recommended for improving the reliability of phylogenetic inference [36] [37]. Soler et al. (2004) [35] proved that $r p o D$ and $g y r B$ housekeeping genes, independently, are excellent molecular makers for assessing phylogeny in the genus Aeromonas, which suggest that horizontal transfer maybe not occur between closely species, but yet may occur between other taxonomic levels.

Hydrocarbon catabolism genes are largely distributed in bacteria and many of them are located in plasmids [38] [39] [40]. Many studies showed HGT occurring between bacteria with genes involved with catabolism of distinct hydrocarbons and plasmids are closely related with this process [22] [41] [42], this may explain the divergence of topologies of trees obtained by Bayesian Inference analysis from sequences of the hydrocarbon catabolism and housekeeping genes. Polycyclic aromatic hydrocarbon (PAH) degrading bacteria are known by its ability of transfer horizontally these genes inside the community, one example is the Catechol 1,2-Dioxygenase (catA) [39] [40] [42].

Bacterial alkane degradation is important for the bioremediation of petroleum-contaminated environments since these compounds are predominant in crude oil [43] [44]. A number of bacteria have multiple alkane hydroxylase genes which proven to potentially expand the $n$-alkane range of the host strain [45]. More than 60 genus of aerobic bacteria and 5 genus of anaerobic bacteria have been reported to be able to degrade $n$-alkanes [46] [47]. Some Rhodococcus strains are known to contain more than one alkB homologous genes, which have different substrate ranges and induction styles [48] [49]. These facts corroborate with the ability of the alkane hydroxylase genes to be spread in the microbial community by HGT.

High molecular weight hydrocarbons and the PAH caused chronic effects on the biota, because its recalcitrant properties, low solubility and hard to volatilization makes it will remain a long time on the environment [50] [51]. The PAH may be adsorbed to particular matter in suspension on water and consequently deposited in the sediment, which become a contaminant reservoir, playing ecotoxicological effects to marine biota [52] [53]. The HGT may be used with the purpose to spread hydrocarbon catabolism genes within of bacterial community to metabolyze faster the environmental contaminants in marine ecosystems.

\section{Conclusion}

The genotypic plasticity ability of the bacterial community to adapt on different 
environments is a great evidence of the occurrence of horizontal gene transfer in nature. On this way, we conclude that phylogenetic tools can be useful for inferring horizontal transfer events through the comparison with tree obtained by $16 \mathrm{~S}$ rRNA sequence analysis. In this way, hydrocarbons catabolism genes as well housekeeping genes can be subject to horizontal gene transfers. The spreading of catabolic routes genes on the bacterial community provides a great diversity of ecological niches. In this way, bioaugmentation strategies can consider the ability of HGT to accelerate the hydrocarbons degradation in natural environments.

\section{References}

[1] Olsen, G.J., Lane, D.J., Giovannoni, S.J. and Pace, N.R. (1986) Microbial Ecology and Evolution: A Ribosomal RNA Approach. Annual Review of Microbiology, 40, 337-365. https://doi.org/10.1146/annurev.mi.40.100186.002005

[2] Woese, C.R., Kandler, O. and Wheelis, M.L. (1990) Towards a Natural System of Organisms: Proposal for the Domains Archaea, Bacteria, and Eucarya. Proceedings of the National Academy of Sciences of the United States of America, 87, 4576-4579. https://doi.org/10.1073/pnas.87.12.4576

[3] Sasser, M. (2001) Identification of Bacteria by Gas Chromatography of Cellular Fatty Acids. Technical Note 101. Microbial ID, Inc., Newark, Del.

[4] Zuckerkandl, E. and Pauling, L. (1965) Molecules as Documents of Evolutionary History. Journal of Theoretical Biology, 8, 357-366. https://doi.org/10.1016/0022-5193(65)90083-4

[5] Tang, Y.-W., Ellis, N.M., Hopkins, M.K., Smith, D.H., Dodge, D.E. and Persing, D.H. (1998) Comparison of Phenotypic and Genotypic Techniques for Identification of Unusual Aerobic Pathogenic Gram-Negative Bacilli. Journal of Clinical Microbiology, 36, 3674.

[6] Ochman, H., Lawrence, J.G. and Groisman, E.A. (2000) Lateral Gene Transfer and the Nature of Bacterial Innovation. Nature, 405, 299-304.

https://doi.org/10.1038/35012500

[7] Thomas, C. and Nielsen, K. (2005) Mechanisms of, and Barriers to, Horizontal Gene Transfer between Bacteria. Nature Reviews Microbiology, 3, 711-721. https://doi.org/10.1038/nrmicro1234

[8] Nakamura, Y., Itoh, T., Matsuda, H. and Gojobori, T. (2004) Biased Biological Functions of Horizontally Transfered Genes in Prokaryotic Genomes. Nature Genet, 36, 760-766. https://doi.org/10.1038/ng1381

[9] Miyazaki, R., Minoia, M., Pradervand, N., Sulser, S., Reinhard, F. and Meer, J.R. (2012) Cellular Variability of RpoS Expression. Underlies Subpopulation Activation of an Integrative and Conjugative Element. Plos Genetics, 8, e1002818. https://doi.org/10.1371/journal.pgen.1002818

[10] Riser-Roberts, E. (1992) Bioremediation of Petroleum Contaminated Sites. CRC Press, Boca Raton, FL.

[11] Aske, N., Kallevik, H. and Sjöblom, J. (2002) Water-in-Crude Oil Emulsion Stability Studied by Critical Electric Field Measurements. Correlation to Physico-Chemical Parameters and Near-Infrared Spectroscopy. Journal of Petroleum Science and Engineering, 36, 1-17. https://doi.org/10.1016/S0920-4105(02)00247-4

[12] Ghazali, F.M., Rahman, R.N.Z.A., Salleh, A.B. and Basri, M. (2004) Biodegradation of Hydrocarbons in Soil by Microbial Consortium. International Biodeterioration \& 
Biodegradation, 54, 61-67. https://doi.org/10.1016/j.ibiod.2004.02.002

[13] La Rocca, C., Conti, L., Crebelli, R., Crochi, B., Iacovella, N., Rodriguez, F., Turrio-Baldassarri, L. and di Domenico, A. (1996) PAH Content and Mutagenicity of Marine Sediments from the Venice Lagoon. Ecotoxicology and Environmental Safety, 33, 236-245. https://doi.org/10.1006/eesa.1996.0030

[14] Ritter, K.S. and Paul, S.L. (2002) Sources, Pathways, and Relative Risks of Contaminants in Surface Water and Groundwater: A Perspective Prepared for the Walkerton Inquiry. Journal of Toxicology and Environmental Health, Part A, 65, 1-142. https://doi.org/10.1080/152873902753338572

[15] Chen, G. and White, P.A. (2004) The Mutagenic Hazards of Aquatic Sediments: A Review. Mutation Research, 567, 151-225. https://doi.org/10.1016/j.mrrev.2004.08.005

[16] Shimada, T. and Fujii-Kuriyama, Y. (2004) Metabolic Activation of Polycyclic Aromatic Hydrocarbons to Carcinogens by Cytochromes P450 1A1 and 1B1. Cancer Science, 95, 1-6. https://doi.org/10.1111/j.1349-7006.2004.tb03162.x

[17] Whitehead, A. (2013) Interactions between Oil-Spill Pollutants and Natural Stressors Can Compound Ecotoxicological Effects. Integrative and Comparative Biology, 53, 635-647. https://doi.org/10.1093/icb/ict080

[18] Cerniglia, C.E. (1992) Biodegradation of Polycyclic Aromatic Hydrocarbons. Biodegradation, 3, 351-368. https://doi.org/10.1007/BF00129093

[19] McCay, D.F., Rowe, J.J., Whittier, N., Sankaranarayanan, S. and Etkin, D.S. (2004) Estimation of Potential Impacts and Natural Resource Damages of Oil. Journal of Hazardous Materials, 107, 11-25. https://doi.org/10.1016/j.jhazmat.2003.11.013

[20] Rodrigues, E. and Tótola, M. (2015) Petroleum: From Basic Features to Hydrocarbons Bioremediation in Oceans. Open Access Library Journal, 2, 1-17. https://doi.org/10.4236/oalib.1102136

[21] Rodrigues, E., Morais, D., Pylro, V., Redmile-Gordon, M., Oliveira, J., Roesch, L., Cesar, D. and Tótola, M. (2017) Aliphatic Hydrocarbon Enhances Phenanthrene Degradation by Autochthonous Prokaryotic Communities from a Pristine Seawater. Microbial Ecology. https://doi.org/10.1007/s00248-017-1078-8

[22] Obayori, O.S. and Salam, L.B. (2010) Degradation of Polycyclic Aromatic Hydrocarbons: Role of Plasmids. Scientific Research and Essays, 5, 4093-4106.

[23] Johnsen, A.R., Wick, L.Y. and Harms, H. (2005) Principles of Microbial PAH-Degradation in Soil. Environmental Pollution, 133, 71-84. https://doi.org/10.1016/j.envpol.2004.04.015

[24] Foght, J.M. and Westlake, D.W. (1996) Transposon and Spontaneous Deletion Mutants of Plasmid-Borne Genes Encoding Polycyclic Aromatic Degradation by a Strain of Pseudomonas fluorescens. Biodegradation, 7, 353-366. https://doi.org/10.1007/BF00115749

[25] Top, E.M. and Springael, D. (2003) The Role of Mobile Genetic Elements in Bacterial Adaptation to Xenobiotic Organic Compounds. Current Opinion in Biotechnology, 14, 262-269. https://doi.org/10.1016/S0958-1669(03)00066-1

[26] Bosma, T.N.P., Harms, H. and Zehnder, A.J.B. (2001) Biodegradation of Xenobiotics in Environment and Technosphere. In: Beek, B., Ed., The Handbook of Environmental Chemistry Vol. 2 Part K, Biodegradation and Persistence, Springer-Verlag, Berlin, Heidelberg, 163-202. https://doi.org/10.1007/10508767_2

[27] Tamura, K., Stecher, G., Peterson, D., Filipski, A. and Kumar, S. (2013) MEGA6: Molecular Evolutionary Genetics Analysis Version 6.0. Molecular Biology and Evo- 
Iution, 30, 2725-2729. https://doi.org/10.1093/molbev/mst197

[28] Yang, Z. and Ranalla, B. (1997) Bayesian Phylogenetic Inference Using DNA Sequences: A Markov Chain Monte Carlo Method. Molecular Biology and Evolution, 14, 717-724. https://doi.org/10.1093/oxfordjournals.molbev.a025811

[29] Huelsenbeck, J.P. and Ronquist, F. (2001) MRBAYES: Bayesian Inference of Phylogenetic Trees. Bioinformatics Applications Note, 17, 754-755. https://doi.org/10.1093/bioinformatics/17.8.754

[30] Smith, S.E., Showers-Corneli, P., Dardenne, C.N., Harpending, H.H., Martin, D.P. and Beiko, R.G. (2012) Comparative Genomic and Phylogenetic Approaches to Characteriza the Role of Genetic Recombination in Mycobacterial Evolution. PLoS $O N E$, 7, e50070. https://doi.org/10.1371/journal.pone.0050070

[31] Arenskötter, M., Bröker, D., Arensko, M., Bro, D. and Steinbu, A. (2004) Biology of the Metabolically Diverse Genus Gordonia Biology of the Metabolically Diverse Genus Gordonia. Applied and Environmental Microbiology, 70, 3195-3204. https://doi.org/10.1128/AEM.70.6.3195-3204.2004

[32] Shen, F.-T., Lu, H.-L., Lin, J.-L., Huang, W.-S., Arun, A.-B. and Young, C.-C. (2006) Phylogenetic Analysis of Members of the Metabolically Diverse Genus Gordonia Based on Proteins Encoding the gyrB Gene. Research in Microbiology, 157, 367-375. https://doi.org/10.1016/j.resmic.2005.09.007

[33] Jeffroy, O., Brinkmann, H., Delsuc, F. and Philippe, H. (2006) Phylogenomics: The Beginning of Incongruence? Trends in Genetics, 22, 225-231.

https://doi.org/10.1016/j.tig.2006.02.003

[34] Yamamoto, S. and harayama, S. (1998) Phylogenetic Relationships of Pseudomonas putida Strains Deduced from the Nucleotide Sequences of gyrB, rpoD and $16 \mathrm{~S}$ rRNA Genes. International Journal of Systematic Bacteriology, 48, 813-819. https://doi.org/10.1099/00207713-48-3-813

[35] Soler, L., Yánez, M.A., Chacon, M.R., Aguilera-Arreola, M.G., Catalán, V., Figueras, M.J. and Martínez-Murcia, A.J. (2004) Phylogenetic Analysis of the Genus Aeromonas Based on Two Housekeeping Genes. International Journal of Systematic and Evolutionary Microbiology, 54, 1511-1519. https://doi.org/10.1099/ijs.0.03048-0

[36] Stackebrandt, E., Frederiksen, W., Garrity, G.M., Grimont P.A.D., Kampfer, P., Maiden, M.C.J., Nesme, X., Rosselló-Mora, R., Swings, J., Truper, H.G., Vauterin, L., Ward, A.C. and Whitman, W.B. (2002) Report of the Ad Hoc Committee for the Re-Evaluation of the Species Definition in Bacteriology. International Journal of Systematic and Evolutionary Microbiology, 52, 1043-1047.

[37] Heled, J. and Drummond, A.J. (2010) Baysian Inference of Species Trees from Multilocus Data. Molecular Biology and Evolution, 27, 570-580. https://doi.org/10.1093/molbev/msp274

[38] Leahy, J.G. and Colwell, R.R. (1990) Microbial Degradation of Hydrocarbons in the Environment. Microbiological Reviews, 54, 305-315.

[39] Wilson, M.S., Harrick, J.B., Jeon, C.O., Hinman, D.E. and Madsen, E.L. (2003) Horizontal Transfer of phnAc Dioxygenase Genes within One og Two Phenotypically and Genotypically Distinctive Naphthalene-Degrading Guilds from Adjacent Soil Environments. Applied and Environmental Microbiology, 69, 2172-2181. https://doi.org/10.1128/AEM.69.4.2172-2181.2003

[40] Ma, Y., Wang, L. and Shao, Z. (2006) Pseudomonas, the Dominant Polycyclic Aromatic Hydrocarbon-Degrading Bacteria Isolated from Antartic Soils and the Role of Large Plasmids in Horizontal Gene Transfer. Environmental Microbiology, 8, 455-465. https://doi.org/10.1111/j.1462-2920.2005.00911.x 
[41] Atlas, R.M. (1981) Microbial Degradation of Petroleum Hydrocarbons: An Environmental Perspective. Microbiological Reviews, 45, 180-209.

[42] Habe, H. and Omori, T. (2003) Genetics of Polycyclic Aromatic Hydrocarbon Metabolism in Diverse Aerobic Bacteria. Bioscience, Biotechnology, and Biochemistry, 67, 225-243. https://doi.org/10.1271/bbb.67.225

[43] Coates, J.D., Woodward, J., Allen, J., Philp, P. and Lovley, D.R. (1997) Anaerobic Degradation of Polycyclic Aromatic Hydrocarbons and Alkanes in Petroleum-Contaminated Marine Harbor Sediments. Applied and Environmental Microbiology, 63, 3589-3593.

[44] Nie, Y., Chi, C.Q., Fang, H., Liang, J.L., Lu, S.L., Lai, G.L., Tang, Y.Q. and Wu, X.L. (2014) Diverse Alkane Hydroxylase Genes in Microorganisms and Environments. Scientific Reports, 4, 4968-4978.

[45] van Beilen, J.B., Funhoff, E., van Loon, A., Just, A., Jaysser, L., Bouza, M., Holtackers, R., Rothisberger, M., Li, Z. and Witholt, B. (2006) Cytochrome P450 Alkane Hydroxylases of the CYP153 Family Are Common in Alkane-Degrading Eubacteria Lacking Integral Membrane Alkane Hydroxylases. Applied and Environmental Microbiology, 72, 59-65. https://doi.org/10.1128/AEM.72.1.59-65.2006

[46] Prince, R.C. (2005) The Microbiology of Marine Oil Spill Bioremediation. In: Ollivier, B. and Magot, M., Eds., Petroleum Microbiology, ASM Press, Washington DC, 317-336. https://doi.org/10.1128/9781555817589.ch16

[47] Rodrigues, E.M., Kalks, K.H.M. and Tótola, M.R. (2015) Prospect, Isolation, and Characterization of Microorganisms for Potential Use in Cases of Oil Bioremediation along the Coast of Trindade Island. Journal of Environmental Management, 156, 15-22. https://doi.org/10.1016/j.jenvman.2015.03.016

[48] Whyte, L.G., Smits, T.H.M., Labbe, D., Witholt, B., Greer, C.W. and van Beilen, J.B. (2002) Gene Cloning and Characterization of Multiple Alkane Hydroxylase Systems in Rhodococcus Strains Q15 and NRRL B-16531. Applied and Environmental Microbiology, 68, 5933-5942. https://doi.org/10.1128/AEM.68.12.5933-5942.2002

[49] Amouric, A., Quemeneur, M., Grossi, V., Liebgott, P., Auria, R. and Casalot, L. (2009) Identification of Different Alkane Hydroxylase Systems in Rhodococcus Ruber Strain SP2B, an Hexane-Degrading Actinomycete. Journal of Applied Microbiology, 108, 1903-1916. https://doi.org/10.1111/j.1365-2672.2009.04592.x

[50] Atlas, R.M. (1991) Microbial Hydrocarbon Degradation-Bioremediation Oil Spills. Journal of Chemical Technology and Biotechnology, 52, 149-156. https://doi.org/10.1002/jctb.280520202

[51] Haritash, A.K. and Kaushik, C.P. (2009) Biodegradation Aspects of Polycyclic Aromatic Hydrocarbons (PAHs): A Review. Journal of Hazardous Materials, 169, 1-15. https://doi.org/10.1016/j.jhazmat.2009.03.137

[52] Simpson, C.D., Mosi, A.A., Cullen, W.R. and Reimer, K.J. (1996) Composition and Distribution of Polycyclic Aromatic Hydrocarbon Contamination in Surficial Marine Sediments from Kitimat Harbor, Canada. Science of the Total Environment, 181, 265-278. https://doi.org/10.1016/0048-9697(95)05026-4

[53] Morales-Caselles, C., Jiménez-Tenorio, N., de Canales, M.L.G., Sarasquete, C. and DelValls, T.A. (2006) Ecotoxicity of Sediments Contaminated by the Oil Spill Associated with the Tanker "Prestige" Using Juveniles of the Fish Sparus aurata. Archives of Environmental Contamination and Toxicology, 51, 652-660. https://doi.org/10.1007/s00244-005-0251-0 